\title{
Tax Cost Control of Personal Remuneration for Female Workers with Two Children under the New Tax Policy
}

\author{
Yu Liao* \\ Department of Economics and Management \\ City College of Wuhan University of Science and \\ Technology \\ Wuhan, China
}

\author{
Jing Chen \\ Department of Economics and Management \\ City College of Wuhan University of Science and \\ Technology \\ Wuhan, China
}

\begin{abstract}
The purpose of the work is a study of how women can better avoid taxes under the new tax policy. With the rapid development of market economy in China, the competition between various enterprises has become more and more intense in recent years. Female employees actively participate in social labor and become a force that can't be ignored in the workplace. However, in the employment process of enterprises in China, discrimination against women and the situation of low pay of female employees is still common. How to help the female employees of two children to reasonably carry out tax planning is the key issue. Based on the analysis of the salary level of female employees, this paper discusses the comparison scheme of the tax cost control of female employees 'pay under the new tax policy and puts forward some measures to reduce the tax cost of female employees' pay. The article compared the situation of female employees 'income tax before and after the new personal income tax policy and proposes that using the tax relief allowed by the policy has helped individuals to minimize tax expenditure.
\end{abstract}

Keywords—woman; compensation; personal income tax; cost

\section{INTRODUCTION}

Women are half of the country. Women's employment can't only bring more income to the family, but also provide more impetus for the development of society. In recent years, new achievements have been made in the cause of women in China. Women's employment has continued to expand, the number of poor women in rural areas has been drastically reduced, and women's equal rights have been strongly guaranteed. With the progress of Chinese society, it has enabled tens of millions of women to participate more deeply in the magnificent social practices. They have the same vast sky as men. Women have also become a great force for the Advancement of social civilization. The status and value of women in the family and society have been more and more affirmed and recognized, but women's rights protection still faces many problems.

Under the comprehensive two-child policy, according to some surveys, only about 28.8 percent of women of childbearing age have made it clear that they would like to have two children, while the majority of working women do not. One of the main reasons for the low willingness of the

Fund Project: The scientific research project of Hubei Provincia Department of Education in 2018,"Research on the Career Planning of Women in the Second Child Age", project number: B2018408 second child is the difficulties faced in the workplace. For example, the treatment of ordinary women is lower than that of men. From a global perspective, women's income is on average $24 \%$ lower than that of men. Women account for 83 percent of domestic workers. In terms of retirement age for women, the retirement age for women is now also relatively early, 5 to 10 years earlier. In addition, the early retirement age has led to a significant reduction in the treatment of many women after retirement.

\section{WOMEN'S PARTICIPATION IN SOCIAL WORK AND THEIR} PAY

\section{A. Active participation of female employees in social work}

The female labor force participation rate in China has always been very high. According to statistics, the female labor force participation rate in China and other countries differ greatly. Last year, the female labor force participation rate was $48.5 \%$ in the world, $69.3 \%$ in developing countries, and $52.6 \%$ in developed countries. The female labor force participation rate in China exceeded $63 \%$, ranking first in the world. Among them, the participation rate of Chinese women between the ages of 25 and 55 is as high as $90 \%$. It can be seen that China has the highest female labour force participation rate in the world, not only widening the gap with the BRICS countries, but also surpassing the UK and the United States, maintaining a relatively high level, especially compared with most developed countries and large economies. [1]

\section{B. Increased rate of participation of educated women in social work}

The difficulty of female employment has been widely concerned by society. With the increasing proportion of female students in colleges and universities and the liberalization of the "comprehensive two-child" policy, the pressure on women in the workplace has become more and more severe. The China Labor Market Development Report 2016, published by the Labor Market Center of Beijing Normal University, shows that women's labor participation rate and wages are on average lower than men's, and women's employment and promotion processes are limited. In terms of 
supply, the number of female university students has increased year after year. From 2010 to 2015, the average growth rate of female university graduates was $3.1 \%$ and $2.7 \%$ for men. In the last three years, the proportion of female university graduates has hovered around 51 \%. However, in both 2014 and 2015, the initial employment rate of male university graduates was $10.1 \%$ higher than that of female college student.

In this regard, many experts said that women will face various obstacles in terms of employment, promotion, job stability, and pay, and "hidden discrimination" has become a new trend of female employment.

\section{The fact that women earn less than men has not changed}

On the whole, women's wages are not optimistic. Between 1990 and 2000, the income gap between men and women in China did not narrow, but increased by $7.4 \%$. In 1995, China's gender income ratio was 85.9 percent, while in 2002 it declined slightly to 84.5 percent.2The gender wage gap widened further in 2007, with the gender income ratio falling to 73.9 percent and the gender income ratio rising to 78.2 percent by 2013. Although the gender wage ratio has fluctuated over the years, the overall situation of women earning less than that of men has not changed and there has been an upward trend over the past 10 years. In addition, there is a "glass ceiling" in women's promotion space. According to the report, the proportion of top and senior managers among women is only $13.67 \%$, while the income of women managers is $93.4 \%$ of that of men. However, women have higher levels of education than men, and university degrees or above account for $81.4 \%, 7.1$ percentage points higher than men.

\section{The impact of having two children on women's employment and pay}

With the liberalization of the "two children" policy, many working women and female college students are worried about whether their fertility problems will affect employment and income. Reports showed that the proportion of young urban women with two children who "gave up personal development opportunities for the sake of their families" was as high as 50.98, which was more than 17 percentage points higher than that of young urban women with only one child.

In addition, the phenomenon of "polarization" in female employment is obvious. Among the 19 broad categories, women are concentrated in industries with low entry barriers, technical content and income levels. [2]

\section{E. New technologies affect women's employment and pay}

In light of the three industrial revolutions that have taken place in human society, technology has always existed as a means of overcoming inequality and discrimination. Technology promotes the improvement of productivity, so that the mode of production is continuously optimized, and economic changes lead to institutional changes. In the reconstruction of the superstructure triggered by the economic base, the barriers of ideas, prejudice, and discrimination can be broken.
Now the fourth industrial revolution marked by artificial intelligence is in the ascendant. Compared with the previous three industrial revolutions, the fourth industrial revolution is a significant difference. It is that technology will play an unprecedented role and become the most important production factor. Leading changes. Therefore, the demand for talents in the future will also be biased towards technical talents with professional skills. In the future, cognitive and creative jobs will increase, while repetitive and routine jobs such as administration, media and manufacturing will decrease significantly (TABLE I below). Unfortunately, women are the main force in these "worst-hit areas" (TABLE I below). Because men have long occupied high-performing jobs at the top of the spectrum, women in these industries are likely to bear the brunt of the heavy concentration of women in more alternative basic jobs if skills upgrading is not achieved.

TABLE I. PROSPECTS FOR THE DECLINE IN EMPLOYMENT BY OCCUPATION, 2015-2020

\begin{tabular}{|c|c|}
\hline Industry & $\begin{array}{c}\text { Number of persons reduced } \\
\text { (thousands) }\end{array}$ \\
\hline Office administration & 476 \\
\hline manufacturing industry & 161 \\
\hline Construction & 50 \\
\hline $\begin{array}{c}\text { Arts, design, entertainment, } \\
\text { media }\end{array}$ & 15 \\
\hline law & 11 \\
\hline Installation and maintenance & 4 \\
\hline
\end{tabular}

TABLE II. CHINESE INDUSTRIES WITH RELATIVELY HIGH FEMALE EMPLOYMENT

\begin{tabular}{|c|c|}
\hline Industry & Percentage of employed women \\
\hline Wholesale and retail & $52.75 \%$ \\
\hline Finance & $49.6 \%$ \\
\hline Education & $55.49 \%$ \\
\hline Health, social security and social welfare & $59.63 \%$ \\
\hline
\end{tabular}

From an educational point of view, although the number of female masters is almost the same as that of men, the doctoral group is still dominated by men. Such problems also exist in Western developed countries. According to UNESCO data, women make up only $28 \%$ of researchers worldwide. Women make up less than $20 \%$ of those with postdoctoral degrees in British physics. Even in the United States, where the women's affirmative action movement was most active, female scientists and engineers grew by only 6 percent in the more than two decades between 1993 and 2015. With fewer than a fifth of tech giants like Google, Facebook and Twitter, women currently have no advantage over tech, and risk being replaced by automation. The report of the World Economic Forum showed that men would continue to dominate areas such as computer science, mathematics and engineering and that increased demand for specialized skills might further widen the gender gap. Although there will still be jobs that machines can't replace in the future, such as careers with human characteristics such as psychologists, coaches, physiotherapists, etc., the pattern of male-dominated work is difficult to change. This means that, as now, women are still at risk of being undervalued for these jobs. [3] 
Therefore, how to help female employees gain more benefits in the workplace is the key. The following attempts to study the control of the tax cost of their income.

\section{BASIC MODEL OF PERSONAL INCOME TAX OF EMPLOYEES OF ENTERPRISE}

Personal income tax is a general term for adjusting the legal norms of social relations between taxation agencies and natural persons (residents, non-residents) in the process of income tax collection and administration. Personal income tax is a kind of income tax levied by the state on the income of its own citizens, individuals living in its own territory, and the income derived from its own country by overseas individuals. From September 1, 2011, the amount of tax exemption in mainland China will be adjusted to 3,500 yuan. [4]

On June 19, 2018, the draft amendment to the personal income tax law was submitted to the Third Session of the Standing Committee of the 13th National People's Congress for consideration. This is the seventh overhaul of the tax law since its introduction in 1980. Ushered in a fundamental change: the first comprehensive taxation of four labour-based incomes: wages and salaries, Labour remuneration, remuneration and royalties; The tax threshold was increased from 3,500 yuan per month to 5,000 yuan per month(60,000 yuan per year); For the first time, the children's education expenses, continuing education expenses, medical expenses, housing loan interest, and housing rent, these Special additional deductions will be increased. We will optimize the structure of tax rates and expand the range of lower grade tax rates. The new tax law will be fully implemented on January 1 , 2019. [5]

\section{INDIVIDUAL INCOME TAX PLANNING FOR EARNINGS OF FEMALE EMPLOYEES WITH SECOND CHILD IN ENTERPRISE}

On January 5, 2016, the Central Government issued a document stating that the birth of two children does not require approval and that the family will arrange the birth independently. The policy of opening up two children has been fully implemented. Under this policy, companies that recruit female employees are given an account: In general, female employees in enterprises are entitled to more than five months of maternity leave for the first child, and eligible female employees are entitled to three months of maternity leave for the second child. According to the average salary of 4,000 yuan plus the standard of five insurance and one gold, the company will invest 6,500 yuan per month for female employees who are on maternity leave. The eight-month period of absence from work that will accompany the two births will bring about 50 million yuan to the company. Expenditure. So many companies have scruples.

Suppose, for example, company A, that in 2017 a female employee in a certain department earned the following monthly salary:

TABLE III. THE MONTHLY SALARY OF A COMPANY EMPLOYEE

\begin{tabular}{|c|c|c|c|c|c|c|c|}
\hline Personnel number & name & basic wages & Post salary & subsidy & wage for seniority & Deductions & Total due \\
\hline 1 & Lili & 1800 & 3000 & 100 & 100 & 0.00 & 5000 \\
\hline
\end{tabular}

Assuming that the remuneration in the case of performance rewards is not counted as shown above, if Li Li's performance bonus is a total of 36,000 yuan per year, it is assumed that the payment of performance rewards will be awarded at the end of the year.

Lili monthly taxable income $=5000-(5000 \times 8 \%+5000$ $\times 2 \%+7+5000 \times 0.3 \%+5000 \times 8 \%)-3500=578$ Yuan; Monthly taxable amount $=578 \times 3 \%-0=17.34$ Yuan

Lili's performance bonus 36000 Yuan, $36000 \div 12=3000$ Yuan, If he receives an annual bonus, he should pay income $\operatorname{tax}=36000 \times 10 \%-105=3495$ Yuan Yuan

Annual personal income tax $=17.34 \times 12+3495=3703.08$

What was the situation under the new tax policy in 2019:

lili's Monthly bonus $=36000 \div 12=3000$ Yuan, The amount of his monthly taxable income $=5000+3000-(8000$ $\times 8 \%+8000 \times 2 \%+7+8000 \times 0.3 \%+8000 \times 8 \%)-5000=$ 1529 Yuan; Subamounts fewer items specifically deducted, Monthly taxable amount is 0 Yuan。

In terms of the year, according to the new policy, Lili's annual income $=5000 \times 12+36000=96000$ Yuan
Less social security and housing fund last year: $(8000 \times$ $8 \%+8000 \times 2 \%+7+8000 \times 0.3 \%+8000 \times 8 \%) \times 12=$ 17652 Yuan

Less special deductions for children's education expenditure(12,000 yuan per child per year), housing loan interest expenditure(12,000 yuan per year), and support for the elderly(24,000 yuan per year), totaling 48,000 yuan. After deduction:

$96000-17652-48000=30348$ Yuan, the balance after deducting the deduction of 60,000 yuan is negative, so there is no need to pay taxes.

Under the new policy, which began in 2019, the employee benefited from a tax cut.

\section{OTHER PROPOSALS TO INCREASE THE EARNINGS OF FEMALE EMPLOYEES WITH TWO CHILDREN}

The government should step in and set up mechanisms to share the costs of the impact of maternity on women workers, such as further improving the maternity insurance system, expanding coverage and extending enjoyment time. In addition, when encouraging enterprises and institutions to build nurseries and kindergartens, the government can give appropriate subsidies to nurseries and kindergartens run by 
enterprises. This was done well by the old state-owned enterprises.

Aware of the importance of resolving the conflict between women's work and parental family responsibilities, a number of countries have taken a variety of measures. For example, New Zealand's income from paid maternity leave is paid by the government. While safeguarding women's reproductive and employment rights, a growing number of countries are beginning to recognize the importance of both parents 'participation in the care of infants and young children and are promoting "male maternity leave". Experts believe that this approach, on the one hand, sends a positive message to society that fathers should also perform parental responsibilities. On the other hand, it also reduces the burden of female childcare and helps protect women's employment rights. In recent years, China has adopted policies in this regard. For example, on the basis of the 98 days of maternity leave stipulated in the Special Provisions on the Labour Protection of Female Workers, the revised regulations in various places have increased the number of maternity incentive days or extended maternity leave, which has generally reached 138 to 158 days. There is also paternity leave or nursing leave, which is generally 15 to 30 days. [6]

\section{CONCLUSION}

In short, women can make full use of policy provisions to avoid taxes under the new tax policy. In a time of intense competition, women are increasingly being asked to work in the workplace. Women, especially those with two children, face greater pressure than men. Personnel managers and financial personnel of enterprises can make full use of the benefits of existing policies to help female employees increase their income. This has a profound impact on the future of the nation.

\section{REFERENCES}

[1] Tencent. https://view.news.qq.com/original/intouchtoday/n3906.html.

[2] youth.cn.http://zqb.cyol.com/html/2016 11/28/nw.D110000zgqnb_20161128_7-03.htm.

[3] NeteaseFinance. http://money.163.com/17/0710/08/COVH9BPB00258J1R.html.

[4] Xinliu, compensation(Fifth edition), China Renmin University Press, unpublished. pp. 376-377 (In Chinese)

[5] Xinliu, compensation (Fourth edition), China Renmin University Press, unpublished. pp. 349-350 (In Chinese)

[6] Countries have introduced a number of policies to encourage childbirth: Why foreigners want to have two children, https://new.qq.com/rain/a/20151120001751 (In Chinese) 